\title{
Groundwater Level and Salinity Degradation in Farm Land through Groundwater Pumping Irrigation System in Coastal Area of Takalar Regency
}

\author{
Darwis ${ }^{1}$, Rakhim Nanda ${ }^{1} \&$ Abubakar Idha ${ }^{2}$ \\ ${ }^{1}$ Mecanical Engeneering Faculty, Muhammadyah University of Makassar, Indonesia \\ ${ }^{2}$ Agriculture Faculty, Muhammadyah University of Makassar, Indonesia \\ Correspondence: Darwis Panguriseng, Mecanical Engeneering Faculty, Muhammadyah University of Makassar, \\ Indonesia. E-mail: Darwis_unismuhmks@yahoo.com
}

Received: April 7, $2014 \quad$ Accepted: May 4, $2014 \quad$ Online Published: July 29, 2014

doi:10.5539/mas.v8n4p246 URL: http://dx.doi.org/10.5539/mas.v8n4p246

\begin{abstract}
This study is conducted to find out correlation between released groundwater volume and groundwater level and salinity degradation as well as to find effective infiltration holes formation for groundwater augmentation. It belongs to field experimental research. This study concludes some concerns, they are: (1) Groundwater condition in farm land of coastal area in Takalar Regency has undergone salinization and groundwater salinity escalation in every groundwater release is very high. Groundwater release volume is directly proportional to groundwater salinity escalation with relatively high rate on its escalation gradient; (2) Total degradation of groundwater level in coastal farm land ranges from 14 to $15 \mathrm{~cm}$, and it is relatively low compared to total occurred degradation of groundwater level in observed inner land in early year (ranging from 100 to $150 \mathrm{~cm}$ ); (3) Number of infiltration hole significantly affects escalation volume of augmentation and groundwater salinity rate degradation.
\end{abstract}

Keywords: groundwater, infiltration hole, groundwater irrigation, augmentation, salinity

\section{Introduction}

Groundwater is one of important wellsprings for organism. It is stored in soil layer that is known as aquifer. Aquifer can be found in coastal area, mountainside, valley of inter-mountains, alluvial plain or in karts topographic plain (Voudouris, et al., 2005; Holtz \& Kovacs, 1981). Groundwater utilization should take groundwater conservation factor into account either its quality or quantity (Jumikis A. R., 1969).

Majority residents of Takalar Regency are farmer, and since 1980, they have utilized groundwater for agricultural irrigation purposes (Statistical of Takalar Regency, 2009). Impact of groundwater exploitation carried out by farmer in coastal area has significantly downgraded groundwater quality. Direct threat as the impact of long-term and mass groundwater utilization affects the occurrence of groundwater degradation which creates a cavity space inside of this vulnerable soil layer from saline water of the sea. This condition will raise groundwater salinity and disrupt soil and surface ecosystem balance (Abrol, I. P., 1988)

Problem on contradictory interests between the needs of environmental conservation and ecosystem balance with the farmer's needs to irrigate farm land should be solved. Farmers' needs for water is an absolute to ensure their viability.

Thus, it is impossible to prohibit them to pump groundwater. In the other hand, ecosystem balance should be maintained to ensure land use viability and environmental conservation (Redwood, 2007; ILRI., 1989).

These two matters are similarly absolute in the context of current and future needs as an effort to grant qualified nature and environment to future generations. Therefore, it needs constructive and applicative problem solving which can be implemented by society independently.

Groundwater augmentation had been conducted through well system, composter or biopore infiltration. Related to this study, it uses infiltration system known as "infiltration hole" under consideration that: (1) Hole system infiltration does not alleviate arable land area, such as in infiltration well use; (2) Hole system infiltration has a greater water holding capacity than composter infiltration; (3) Hole system infiltration has a deeper penetration compared to biopore infiltration (Richards, 2010; Scanlon, Healy, \& Cook, 2002; Vries \& Simmers, 2002). 


\section{Research Method}

\subsection{Research Design}

Research design in this study applies field experimental research by means of inferential research. This study is directly conducted in the field which is preceded by observation on farmer's exploited well either toward the change of groundwater level or its salinity.

Furthermore, selection on farmer's exploited well as the object of the study is based on research purpose, that is looking for effective infiltration hole formation in order to reinstate groundwater level and to reform groundwater quality which was intruded by sea water. Then, configuration on infiltration well formation will be made based on the existing soil layer condition and consistency (Wang, 2008) research variables will be executed.There are 3 formations of the observed infiltration hole in this study. They are illustrated as follows:

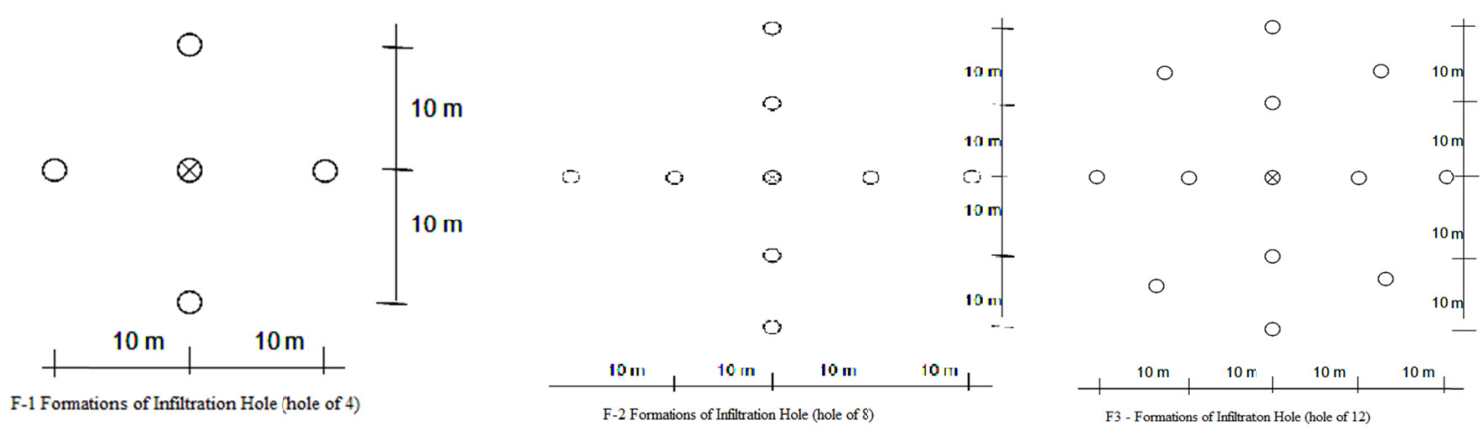

Figure 1. Three formations of infiltration hole

Based on this research hypothesis, that the more infiltration holes, the more optimal augmentation. However, according to the use in farmer's level, if the amount of infiltration hole is more than 12 holes, it is considered as inefficient compared to potential of their harvest. Hence, initial phase in this study is by limiting infiltration hole up to 12 holes under expectation that this method will be applied by farmers who use groundwater irrigation as arranged by local government regulation in Takalar Regency.

\subsection{Data Collection}

Observation and variable measurement in this study is conducted based on standard indicators, they are:

Object selection on farmer's exploited well; it is conducted based on the daily existing groundwater level compared to groundwater level in the land where the groundwater had not been exploited.

Object selection on groundwaters' salinity test in coastal area is based on daily groundwater salinity under salinity rate above $0.5 \mathrm{ppt}$ (brackish water).

Observation on groundwater level elevation, capacity of groundwater exploitation, recovery time of groundwater level and salinity are conducted in every occurred conditional changes either of given treatment (pumping) or seasonal condition (rain).

Those exclusive criterion above will become operational guidelines for observation and data sampling in the field (Taheri, Fryar, \& Akbari, 2007; Bouwer, 2002), besides it will accommodate the occurred inclusive criterion in every observation phases in the field.

\subsection{Data Processing}

Obtained data from observation will be deductively and comparatively processed in order to gain information on the effectiveness of every built infiltration well configuration either for soil cavity restocking to reinstate groundwater level elevation or for sea water suppression from the intruded layer Van Duijvenbode SW, Olsthoorn TN (2002).

Data of observation result which is obtained from all research variables will be numerically processed and graphically illustrated. Based on this process, entire existed treatment effects and changes in the field will be observable.

\subsection{Data Analysis}

To determine effectiveness of each infiltration well configuration types, there will be inferential analysis either 
for its effectiveness value toward groundwater level recovery or its groundwater salinity recovery that were intruded by sea water.

Such selection on data analysis method aims to gain comparative illustration from the whole observed wells in order to compatibly observe all of the existing phenomena as well as to help drawing conclusion.

\section{Research Results}

In a broad outline, observation results can be divided into two parts, they are: (1) Data of groundwater level change; it indicate groundwater degradation and groundwater salinity escalation in consequence of conducted pumping (extrication) during dry season. (2) Data of groundwater level escalation and groundwater salinity degradation in consequence of occurred augmentation during rainy season by observing 3 wells with different amount of infiltration hole.

Obtained result from observation during groundwater release and during augmentation are presented below:

\subsection{Observation Result on Groundwater Release}

By the time of groundwater release, the most interesting phenomena to be observed are; relationship between the released groundwater volume and groundwater level degradation and relationship between released groundwater volume and groundwater salinity escalation. Those relationships can be seen in the following Figures:

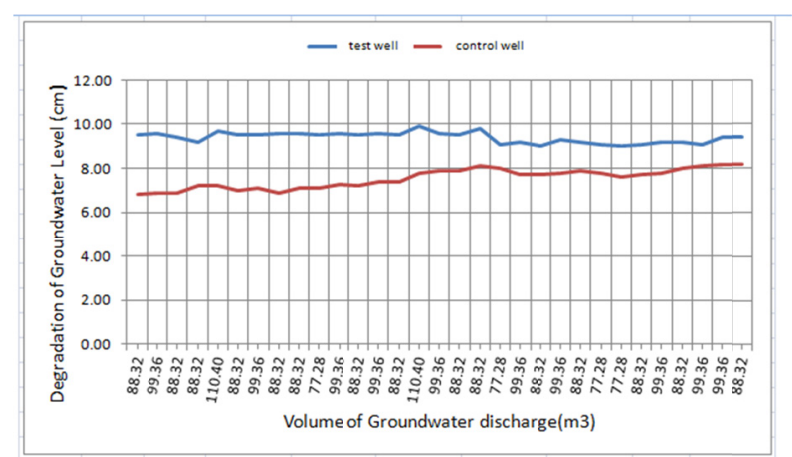

Figure 2. Relationship between Groundwater Volume vs. Groundwater Level Degradation

(Pakkabba-1: 12-infiltration wells)

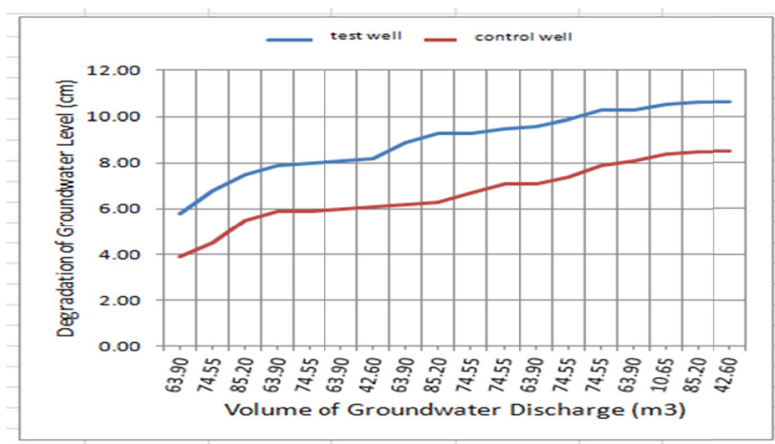

Figure 4. Relationship between Groundwater Volume vs. Groundwater Level Degradation (Pakkabba-3: 4-infiltration wells)

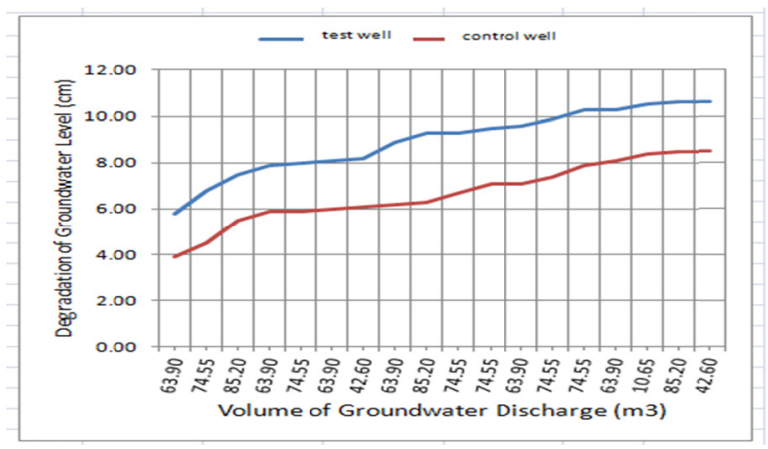

Figure 3. Relationship between Groundwater Volume vs. Groundwater Level Degradation (Pakkabba-2: 8-infiltration wells)

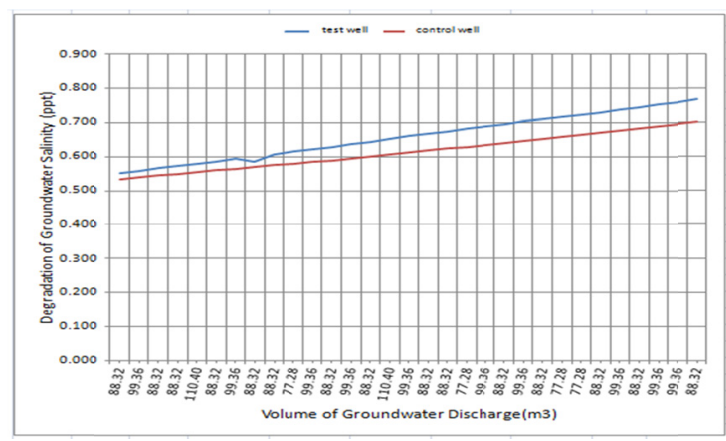

Figure 5. Relationship between Total Groundwater Volume vs. Total Groundwater Level Degradation (3-Locations) 


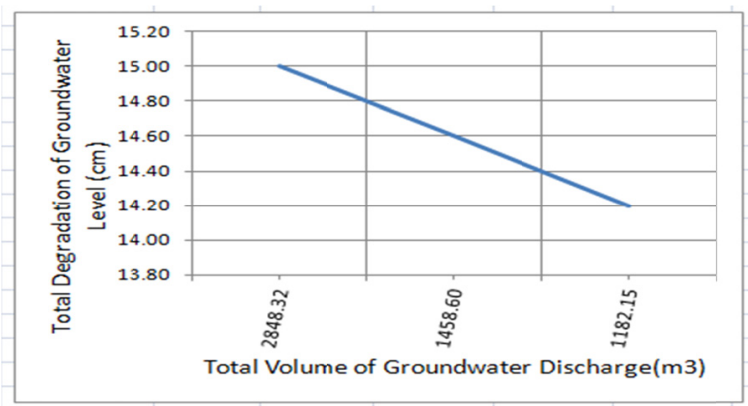

Figure 6. Relationship between Groundwater Volume vs. Groundwater Salinity Degradation (Pakkabba-1: 12-infiltration wells)

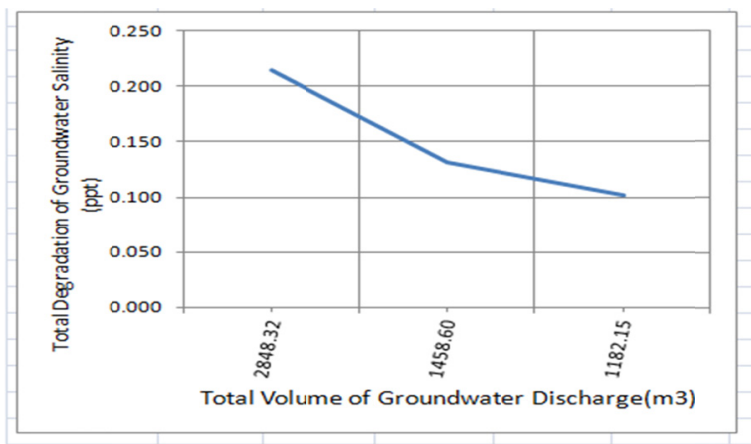

Figure 8. Relationship between Groundwater Volume vs. Groundwater Salinity Degradation (Pakkabba-3: 4-infiltration wells)

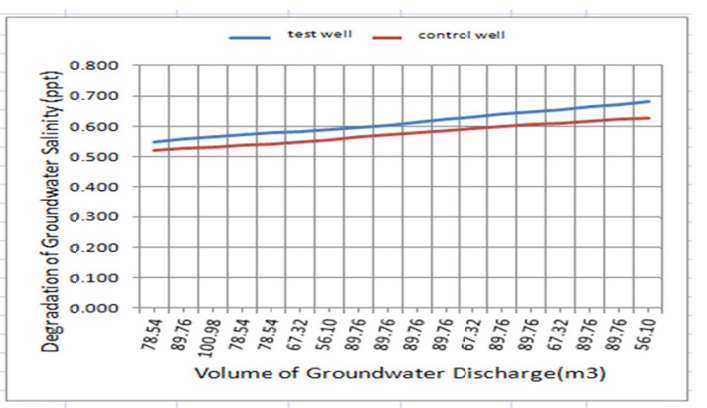

Figure 7. Relationship between Groundwater Volume vs. Groundwater Salinity Degradation (Pakkabba-2: 8-infiltration wells)

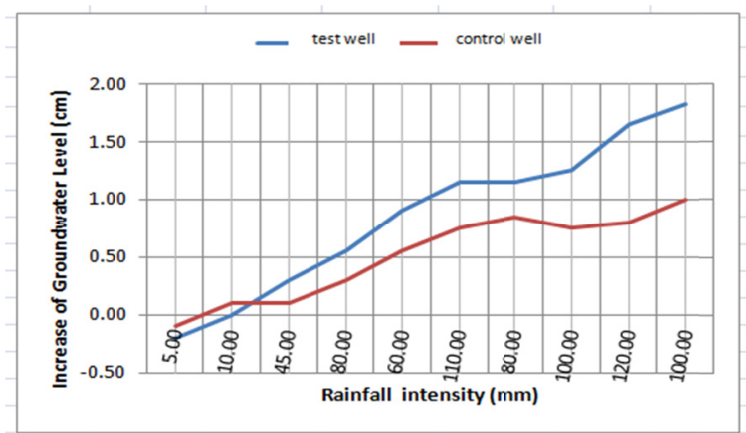

Figure 9. Relationship between Total Groundwater Dischange vs. Total Salinity Degradation (3-Locations)

\subsection{Data on Observed Groundwater Augmentation}

When the rain comes, groundwater augmentation occurs and the most interesting data to be observed are relationship between rainfall and groundwater level escalation and relationship between rainfall and groundwater salinity degradation in the observed well. From the 3 research sites in this study, those relationships can be seen in the following illustrated graphics:

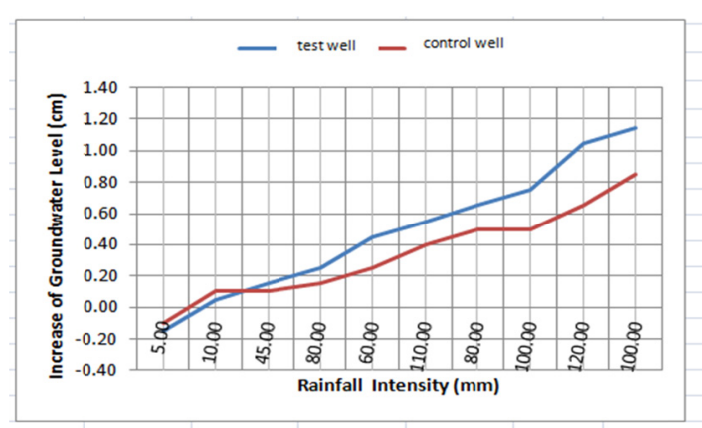

Figure 10. Relationship between Rainfall Intensity vs) Groundwater Level (Pakkabba-1: 12-infiltration wells

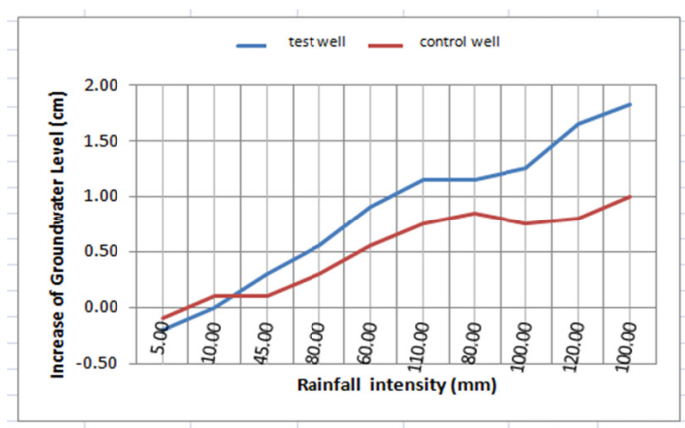

Figure 11. Relationship between Rainfall Intensity vs. Groundwater Level (Pakkabba-2: 8-infiltration wells) 


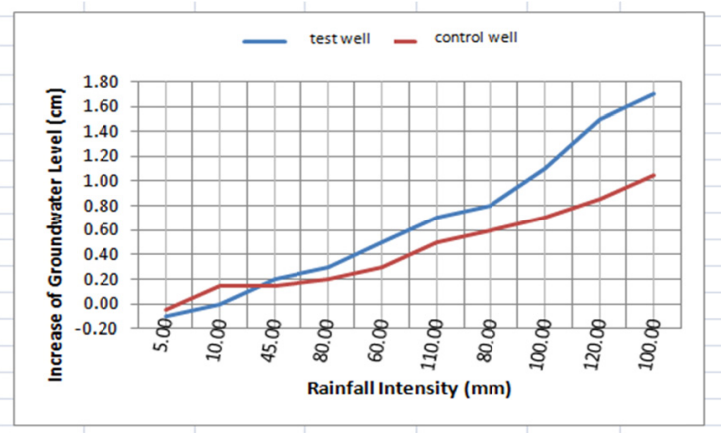

Figure 12. Relationship between Rainfall Intensity vs. Groundwater Level (Pakkabba-3: 4-infiltration wells)

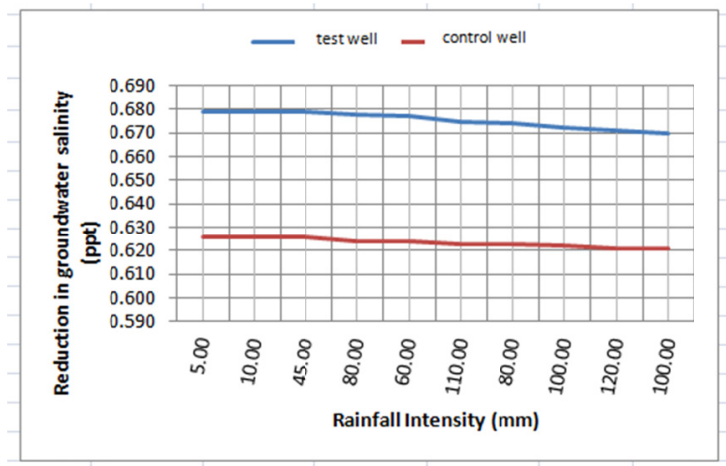

Figure 14. Relationship between Rainfall vs. Groundwater Salinity Degradation (Pakkabba-1: 12-infiltration wells)

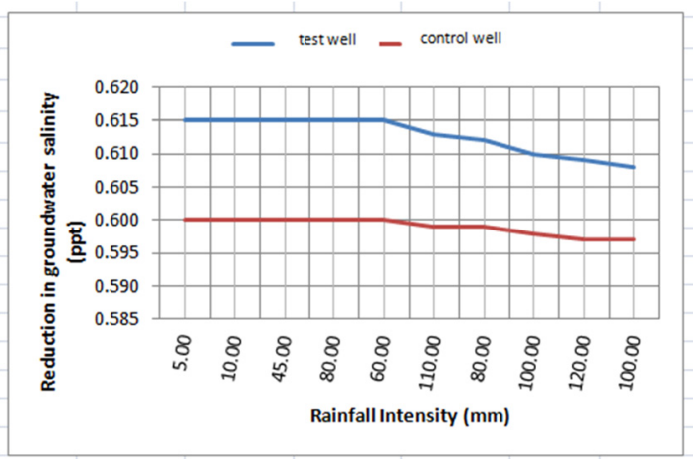

Figure 16. Relationship between Rainfall vs. Groundwater Salinity Degradation (Pakkabba-3: 4-infiltration wells)

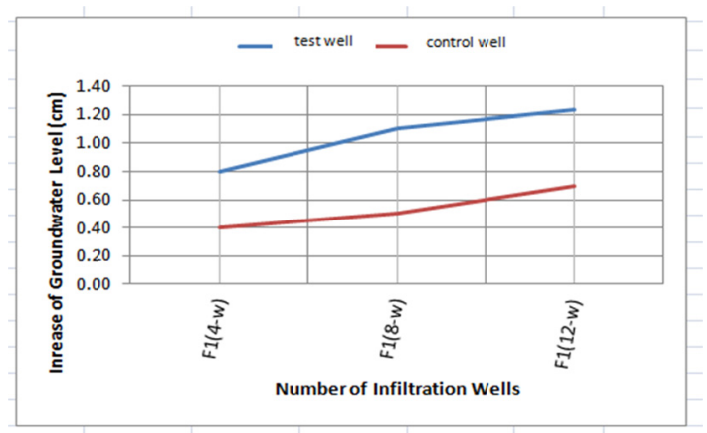

Figure 13. Relationship between Number of Infiltration Well vs. Groundwater Level Escalation (3-Locations)

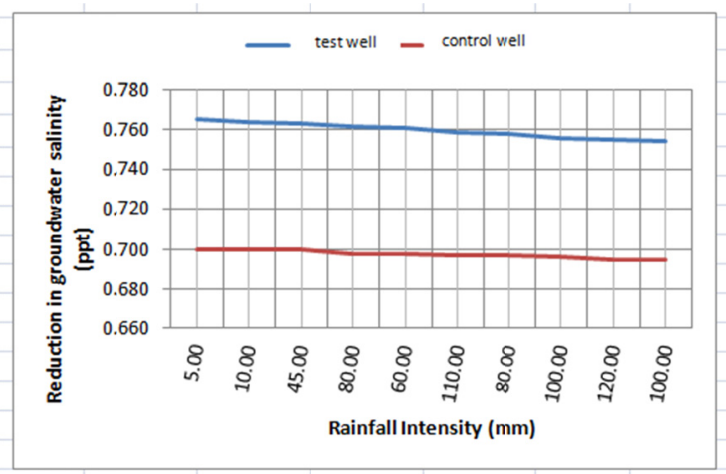

Figure 15. Relationship between Rainfall vs. Groundwater Salinity Degradation (Pakkabba-2: 8 -infiltration wells)

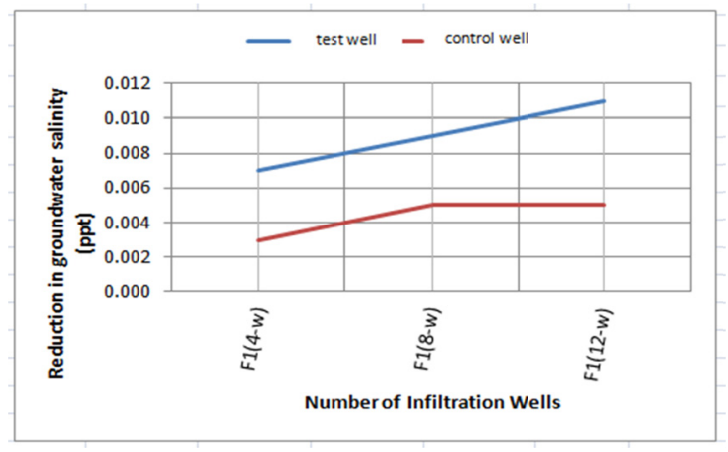

Figure 17. Relationship between Number of infiltration Well vs Groundwater Salinity Degradation (3-locations)

\section{Discussion}

\subsection{Relationship between Groundwater Release Volume and Groundwater Level Degradation}

Figure 2, 3 and 4 show correlation between groundwater volume release and groundwater level degradation in these three observed wells. There are some interesting phenomena to be observed and to be discussed, they are:

1) For an area within a radius of $60 \mathrm{~m}$, groundwater level is influenced by groundwater release process in consequence of exploited well. It can be seen from those three controlled wells with a distance of 50,55 and $60 \mathrm{~m}$ from the observed well. All of them had groundwater level degradation when each of groundwater pumping is executed. 
2) Degradation rate of groundwater level in consequence of coastal pumping is relatively lower that degradation rate occurred in inner land area.

Other than the phenomenon, another phenomenon is found that recovery time of groundwater level after groundwater release in those three observed wells is relatively fast. It indicates that soil layer of groundwater basin zone in coastal area of Takalar has relatively high permeability and it tends to be similar in the three observed wells.

Another phenomenon is seen in Figure 5 that the greater amount of released groundwater from soil layer, the greater degradation rate of occurred groundwater level.

\subsection{Relationship between Released Groundwater Volume and Groundwater Level Escalation}

Based on Figure 6,7 and 8, it can be seen various phenomena on groundwater salinity at research sites, they are:

1) Groundwater at the observed location have faced salinization and sea water intrusion. It is seen from the initial measurement before groundwater release process that groundwater salinity at those three observed wells have exceeded 0.5 ppt. It means that groundwater salinity in this location have been included in brackish water category.

2) Groundwater salinity escalation occurs when every groundwater release occurs. This phenomenon indicates serious condition. If groundwater exploitation is still being continued without any augmentation effort, it is not only groundwater level degradation which will be occurred, but also substantial problem, i.e., groundwater quality and soil layer degradation.

The other stand-out phenomenon in Figure 9 shows that the greater volume of released groundwater from soil layer, the higher escalation of groundwater salinity.

\subsection{Relationship between Rainfall and Groundwater Level Escalation}

Other than relationship between rainfall intensity and significant escalation of groundwater level, there are some obvious phenomena in Figure 10, 11, and 12 as follows:

1) Similar phenomena which was seen in inner land also occurs in coastal area. This is seen in early rainy season when rainfall intensity is low, groundwater level degradation occurs either in the observed well and controlled well. It is caused by ran off surface water which is gradually infiltrated to fenduler zone, funikuler zone and even to capillary zone. If it occurs, it will engender high temperature in surface area and low pressure on upper soil layer, thus capillary pressure in aquifer will raise. As the consequence, some of groundwater in aquifer (saturation zone) will be pulled up to the upper layer.

2) When augmentation occurs, groundwater level escalation in observed well is faster than groundwater level escalation in controlled well. It occurs because the influence of installed infiltration hole surrounding observed well affects to groundwater augmentation acceleration.

Other than these two phenomena above, Figure 13 shows an indication that greater number of built up infiltration hole surrounding observed well, there will a greater escalation of groundwater level.

\subsection{Relationship between Rainfall and Groundwater Salinity Degradation}

Figure 14, 15 and 16 show relationship between rainfall intensity and significant groundwater salinity degradation. It is also seen some other phenomena as follows:

During low rainfall intensity, there is no effect toward groundwater salinity change and it seems that only high rainfall intensity and rainfall frequency which give a significant effect to groundwater salinity degradation.

1) For augmentation of the observed well with infiltration hole, it seems that there is a faster groundwater salinity degradation compared to the controlled well. It occurs because volume of the infiltrated water in observed well is greater than volume of infiltrated water in controlled well, thus neutralization process of salinity in groundwater of well is faster.

Other than these two phenomena above, Figure 17 also shows an indication that the greater the constructed infiltration hole surrounding observed well, the greater degradation of groundwater salinity.

\subsection{Discussion on the Influence of Irrigation Pump toward Groundwater Level Degradation and Groundwater Salinity}

Illustration as shown in Figure 5 shows relationship between total volume of groundwater release and total degradation of groundwater level in form of linear relationship. It occurs when soil layer in these three research sites are relatively similar; they are in granular soil layer (silty sand). 
Other illustrations also show that during the release process of groundwater in coastal area, total of groundwater degradation is relatively lower than degradation in inner land area. It occurs when coastal area is relatively close to interface zone, then soil cavity restocking process from sea water becomes easier (intrusion process). Based on observation in the field, the phenomenon causing accelerated escalation of groundwater salinity after pumping process on exploited well is quite fast.

Observable phenomenon based on observation toward groundwater salinity change in consequence of groundwater release at research sites indicates that there are salinization process in groundwater caused by sea water intrusion into coastal zone. This is a direct impact of groundwater exploitation for the needs of pulses and rice plant irrigation in the area which have taken place since early 1980s up to now. Exceeded groundwater salinity of $0.5 \mathrm{ppt}$ becomes an indication for local community and government to immediately save groundwater resources through self-made augmentation system. With no augmentation, farm land degradation in this area will be worse, and at last, farmer's potential farm land will be unable to defend their farm business.

\subsection{Effectiveness of Infiltration Hole Number toward Groundwater Augmentation and Salinity Recovery}

Relationship between infiltration holes number and groundwater level escalation shows linear relation (Figure 13). Uniformity factors of soil gradation (silty sand) in the three observed points become causal factors of the phenomena.

By global illustration above, what will be occurred in farm land of coastal area with granular soil layer is faster recovery process either to groundwater level and groundwater salinity recovery in consequence of greater amount of installed infiltration holes surrounding the exploited well.

\section{Conclusion and Suggestion}

\subsection{Conclusion}

1) Groundwater condition at coastal farm land in Takalar Regency have faced salinization; groundwater release volume is directly proportional to groundwater salinity escalation with relative high on its upgrading gradient.

2) Total degradation of groundwater level at coastal farm land is ranging from 14 to $15 \mathrm{~cm}$. This rate is relative low compared to occurred groundwater total degradation in inner land area (ranging from 100 to $150 \mathrm{~cm}$ ). It occurs because sea water supplies soil cavity of inner land when every groundwater pumping is executed in coastal area.

3) Number of infiltration hole significantly affects to volume raise of augmentation and degradation rate of groundwater salinity. In spite of those obvious indications in this study, researcher has not found the optimum number of infiltration hole to recover groundwater level and salinity for coastal area in Takalar due to cost and time limit.

\subsection{Suggestion}

Groundwater degradation in Takalar has lied in critical rate, thus there should be some conservation acts to ensure groundwater sustainability in farm land of Takalar Regency. Here are some suggestions:

1) It is expected that local government of Takalar Regency defines regulation on groundwater use in form of regional regulation which arranges terms and duties which should be complied with by each farmers who utilize groundwater irrigation.

2) It needs follow up research with greater quantity of installed infiltration holes, thus it will be found the optimum amount of infiltration well to supply groundwater as retained from rain water in this area.

\section{References}

Abrol, I. P. (1988). Salt-Affected Soils and their Management. FAO Soils Bulletin Number, 39.

Bouwer, H. (2002). Artificial recharge of groundwater: Hydrogeology and engineering. Hydrogeology Journal, 10, 121-142. http://dx.doi.org/10.1007/s10040-001-0182-4

Holtz \& Kovacs (1981). An Introduction To Geotechnical Engineering. Printice Hall.

ILRI. (1989). Effectiveness and Social/Environmental Impacts of Irrigation Projects. A Review, In: Annual Report 1988 of the International Institute for Land Reclamation and Improvement (ILRI), Wageningen, The Netherlands.

Jumikis, A. R. (1969). Theoritical Soil Mechanics. Van Nostrand Reinhold Company, New York. 
Karl, T., \& Peck, R. B. (1987). Mekanika Tanah dalam Praktek Rekayasa. Terjemahan Agus Witjaksono et.al., Penerbit Erlangga, Edisi Ke-2.

Redwood, J. (2007). Pump/Recharge Rate Affect Saltwater Intrusion. Groundwater Management, Monitoring and Conservation Keep Intrusion Undercontrol", diakses dari http://www.solinst.com, diakses tanggal 29 November 2007.

Richards, W. H. (2010). Estimating of groudwater recharge. University Cambridge Press, England.

Scanlon, B. R., Healy, R. W., \& Cook, P. G. (2002). Choosing appropriate techniques for quantifying groundwater recharge. Hydrogeology Journal, 10, 18-39. http://dx.doi.org/10.1007/s10040-001-0176-2

Taheri, A., \& Zare, M. (2011). Groundwater artificial recharge assessment in Kangavar Basin, a semi-arid region in the western part of Iran. African Journal of Agricultural Research, 6(17), 4370-4384.

Taheri, T. A., Fryar, A. E., \& Akbari, K. (2007). Hydrogeological Framework and Groundwater Modeling of the Sujas Basin, Zanjan Province, Iran. J. Appl. Sci. Asian Network for Scientific Information (ANSI).

Van Duijvenbode, S. W., \& Olsthoorn, T. N. (2002). A pilot study of deep-well recharge by Amsterdam Water Supply(pp. 447-451). Proceedings of the 4th International symposium on artificial recharge of groundwater. SAR-4, A.A. Balkema Publishers, Adelaide, South Australia.

Voudouris, K., Diamantopoulou, P., Giannatos, G., \& Zannis, P. (2005). Groundwater recharge via deep boreholes in the Patras Industrial Area aquifer system. (NW Peloponnesus, Greece). Bull Eng Geol Env., 65, 297-308. http://dx.doi.org/10.1007/s10064-005-0036-8

Vries, J. J., \& Simmers, I. (2002). Groundwater recharge: an overview of processes and challenges. Hydrogeology Journal, 10, 5-17. http://dx.doi.org/10.1007/s10040-001-0171-7

Wang, B., Jin, M., Nimmo, J. R., Yang, L., \& Wang, W. (2008). Estimating groundwater recharge in Hebei Plain, China under varying land use practices using tritium and bromide tracers. Journal of Hydrology, 356, 209-222. http://dx.doi.org/10.1016/j.jhydrol.2008.04.011

\section{Copyrights}

Copyright for this article is retained by the author(s), with first publication rights granted to the journal.

This is an open-access article distributed under the terms and conditions of the Creative Commons Attribution license (http://creativecommons.org/licenses/by/3.0/). 